\title{
Shifts in the Concentrations of Magnesium and Calcium in Early Porcine and Rat Wound Fluids Activate the Cell Migratory Response
}

\author{
John J. Grzesiak and Michael D. Pierschbacher \\ La Jolla Cancer Research Foundation, La Jolla, California 92037
}

\begin{abstract}
Accruing evidence indicates that the levels of extracellular $\mathrm{Mg}^{2+}$ and $\mathrm{Ca}^{2+}$ can have a distinct impact on the adhesive and migratory activities of many cell types. The physiological relevance of these observations, however, has remained largely unexplored. In the present study, wound fluids collected throughout the early stages of cutaneous wound repair were examined for possible $\mathrm{Mg}^{2+}$ and $\mathrm{Ca}^{2+}$ fluctuations. Early in the process, when cell migration into the wound site is initiated, $\mathrm{Mg}^{2+}$ is elevated and $\mathrm{Ca}^{2+}$ is reduced $\left(\mathrm{Mg}^{2+}: \mathrm{Ca}^{2+}=1\right)$. As wound healing progresses, wound fluid concentrations of $\mathrm{Mg}^{2+}$ and $\mathrm{Ca}^{2+}$ begin to return to normal plasma levels $\left(\mathrm{Mg}^{2+}: \mathrm{Ca}^{2+}=0.4\right)$. When macrophages, keratinocytes, fibroblasts, and endothelial cells were exposed to dialyzed wound fluid, the migration stimulated by undialyzed wound fluid was lost. Addition back to dialyzed wound fluid of $24 \mathrm{~h}$, postinjury concentrations of $\mathrm{Mg}^{2+}$ and $\mathrm{Ca}^{2+}$ restored all migratory stimulus. This observed migration is approximately twofold greater than when normal plasma $\mathrm{Mg}^{2+}$ and $\mathrm{Ca}^{2+}$ concentrations are present. Changes in the levels of $\mathrm{Mg}^{2+}$ and $\mathrm{Ca}^{2+}$ in wound fluid occur during the same period that inflammatory cells, keratinocytes, fibroblasts, and neovasculature have been shown to migrate during wound healing in vivo. Together, these data suggest that the impact of these changes on integrins and E-cadherin may play a direct role in the activation and maintenance of the migratory phenotypes of the cells involved in the wound healing process. (J. Clin. Invest. 1995. 95:227-233.) Key words: divalent cations - integrins $\bullet$ Ecadherin • cell migration $\cdot$ wound healing
\end{abstract}

\section{Introduction}

The process of cutaneous wound healing is a complex and carefully orchestrated cascade of overlapping events that involves changes in extracellular matrix protein composition and cell migration and proliferation in response to numerous cytokines (1-4). Crucial to the repair process is the migration of inflammatory cell types such as macrophages and neutrophils and epithelial cells, fibroblasts, and endothelial cells into the wound site over the course of the first $3 \mathrm{~d}$ after injury (1-8), where they have multiple responsibilities resulting, ultimately,

Address correspondence to Dr. M. D. Pierschbacher, La Jolla Cancer Research Foundation, 10901 North Torrey Pines Road, La Jolla, CA 92037. Phone: 619-455-6480; FAX: 619-455-0181.

Received for publication 18 February 1994 and in revised form 8 August 1994.

J. Clin. Invest.

(C) The American Society for Clinical Investigation, Inc.

0021-9738/95/01/0227/07\$2.00

Volume 95, January 1995, 227-233 in a healed wound. Integrins, the family of heterodimeric transmembrane receptors present on the cell surface are responsible for mediating much of the interaction of these cells with the extracellular matrix $(9-12)$.

Integrins require divalent cations, such as $\mathrm{Mg}^{2+}$ and $\mathrm{Ca}^{2+}$, to function (13-16). The integrin $\alpha$ subunits contain the putative EF hand cation-binding domains thought to be responsible for much of the cation binding capacity of integrins $(17,18)$. We have demonstrated with two Arg-Gly-Asp (RGD)-dependent integrins, $\alpha_{\mathrm{v}} \beta_{1}(19,20)$, and $\alpha_{\mathrm{v}} \beta_{3}(21)$, both of which share the same $\alpha$ subunit, that $\alpha_{\mathrm{v}} \beta_{1}$ binds to ligand only in $\mathrm{Mg}^{2+}$ and not in $\mathrm{Ca}^{2+}$, while $\alpha_{\mathrm{v}} \beta_{3}$ binds to ligand in either $\mathrm{Ca}^{2+}$ or $\mathrm{Mg}^{2+}$ (18). We also showed that in the presence of $\mathrm{Mg}^{2+}$, increasing concentrations of $\mathrm{Ca}^{2+}$ enhance the ligand binding of $\alpha_{\mathrm{v}} \beta_{3}$ but inhibit the ligand binding of $\alpha_{\mathrm{v}} \beta_{1}$ (18).

Recently, we reported that the $\mathrm{Mg}^{2+}$-dependent, $\alpha_{2} \beta_{1}$-mediated adhesion and migration of human fibroblasts on type I collagen substrates could be inhibited by elevated extracellular $\mathrm{Ca}^{2+}$. We observed, however, that migration could be enhanced twofold over that seen in $\mathrm{Mg}^{2+}$ alone by providing the two divalent cations in combination with a $\mathrm{Mg}^{2+}$ to $\mathrm{Ca}^{2+}$ ratio slightly higher than one (22). Keratinocytes are also important in the cutaneous wound repair process, and the concentrations of extracellular $\mathrm{Mg}^{2+}$ and $\mathrm{Ca}^{2+}$ have been observed to affect their $\alpha_{2} \beta_{1}$-mediated migration on type I collagen in a similar fashion. ${ }^{1}$ In addition to integrins, keratinocytes express another $\mathrm{Ca}^{2+}$-dependent molecule responsible for cell-cell adhesion, E-cadherin (for reviews see references 23 and 24). In the presence of $\mathrm{Ca}^{2+}, \mathrm{E}$-cadherin resides principally in the areas of cellcell contacts. In reduced $\mathrm{Ca}^{2+}$, however, E-cadherin becomes susceptible to proteolytic cleavage and rapidly loses function, eventually disappearing from the cell surface altogether. Recent studies demonstrate the differential regulation of E-cadherin and the integrin $\alpha_{2} \beta_{1}$ by shifts in the concentrations of extracellular $\mathrm{Mg}^{2+}$ and $\mathrm{Ca}^{2+}$, resulting in an "activated" keratinocyte phenotype. ${ }^{1}$

Under normal physiologic conditions the concentration of intracellular $\mathrm{Mg}^{2+}$ in the typical mammalian cell is reported to be between 15 and $30 \mathrm{mM}$ and that of $\mathrm{Ca}^{2+}$ is only $\sim 1-2 \mathrm{mM}$ (25-28). On the other hand, extracellular levels of these two cations are about 1.0 and $2.5 \mathrm{mM}$, respectively $(28,29)$. We have speculated, previously, that tissue injury might result in a local increase in the extracellular $\mathbf{M g}^{2+}$ level and/or a decrease in the extracellular $\mathrm{Ca}^{2+}$ level due to the spill of $\mathrm{Mg}^{2+}$ from damaged tissue and the sequestration of $\mathrm{Ca}^{2+}$ by several possible molecular events including the $\mathrm{Ca}^{2+}$-dependent coagulation cascade (30-32). The migratory phenotype of cells involved in wound healing might be supported in the local wound environment and in adjacent surrounding tissue by this diffusible gradient of altered divalent cations. After the required cells have

1. Grzesiak, J. J., and M. D. Pierschbacher, manuscript submitted for publication. 
arrived at the injury site, the extracellular levels of these two cations would be normalized, and the potential for cells to migrate might again be reduced.

In the present study we have examined this hypothesis by measuring the total extracellular $\mathrm{Mg}^{2+}$ and $\mathrm{Ca}^{2+}$ levels in porcine and rat wound fluids during the early phase of cutaneous injury repair when migration of inflammatory cells, keratinocytes, fibroblasts, and neovasculature into the wound site have been shown to occur in vivo (1-8). Our studies indicate an early shift in the levels of these two cations, with elevated extracellular $\mathrm{Mg}^{2+}$ and reduced extracellular $\mathrm{Ca}^{2+}$. We also demonstrate with macrophages on fibrinogen substrates, and keratinocytes, fibroblasts, and endothelial cells on type I collagen substrates that early phase wound fluid stimulates integrinmediated cell migration in a divalent cation-dependent manner. These are specific integrin-extracellular matrix interactions likely to be occurring with these cell types in the type I collagen and fibrin (ogen) rich environment of wound healing (1-8, 33, 34). The inability of dialyzed wound fluid to support such migration could be completely restored by adding back $\mathrm{Mg}^{2+}$ and $\mathrm{Ca}^{2+}$ at the levels observed in wound fluid $24 \mathrm{~h}$ after injury.

The influence of divalent cation concentration on integrin and cadherin function is capable of activating the migratory phenotypes required for the cells involved in wound healing. The ability of wound fluid to achieve this effect has long been known but the factor/s responsible have only been partially elucidated. In this report we demonstrate that the local shift in the extracellular divalent cation concentrations may be a critical part of the cutaneous repair process.

\section{Methods}

Wound fluids. To collect wound fluid three different animal models were used. In the first, two $2-\mathrm{cm}^{2}$ partial thickness excisional wounds were initiated on the dorsal surface of four 4-mo-old female pigs housed and fed together for 2 wk before surgery. Wound fluid was collected by aspirating the wound bed immediately after wounding, centrifuging collected material at $10,000 \mathrm{rpm}$ for $10 \mathrm{~min}$ and collecting the supernatant. Citrated plasma was collected from each animal $1 \mathrm{wk}$ before surgery for determination of normal plasma $\mathrm{Mg}^{2+}$ and $\mathrm{Ca}^{2+}$ levels. In the second model, one $6 \mathrm{~mm}$-diameter-partial-thickness burn wound was generated dorsally on each of two rats (4 mo, male Sprague-Dawley). Necrotic tissue was debrided $24 \mathrm{~h}$ after wound initiation and wound fluid was collected at the indicated time points as described in the porcine model. Citrated plasma was collected $1 \mathrm{~d}$ before wound initiation. In the third animal model, four $1-\mathrm{cm}$-full-thickness incisions were initiated dorsally and $0.25 \times 1 \times 1 \mathrm{~cm}$ sterile polyvinyl alcohol sponges were inserted subcutaneously under the incision. The wounds were then sutured. At the indicated timepoints the sponges were harvested, centrifuged, and the wound fluid collected as with the other models. Citrated plasma was collected on the same day just before surgery and again at the indicated harvest time points. For functional assays, aliquots of wound fluid from individual sponges collected from the full-thickness rat wound $24 \mathrm{~h}$ after injury were dialyzed extensively against divalent cation-free Trisbuffered saline at $4^{\circ} \mathrm{C}$ using dialysis tubing with $6-8 \mathrm{kD}$ molecular mass cutoff.

Magnesium and calcium determination. Atomic absorption spectroscopy was used to evaluate the total $\mathrm{Mg}^{2+}$ and $\mathrm{Ca}^{2+}$ levels in porcine and rat wound fluids. Atomic absorption spectroscopy was carried out by C.L. Technology, Inc. (Corona, CA). Magnesium and calcium kits employing colorimetric methods (Sigma Chemical Co., St. Louis, MO) were also used to confirm results.

Cells. HaCaT cells, spontaneously transformed nontumorigenic human keratinocytes with phenotypic differentiation characteristics of normal keratinocytes (33), and WI38 normal human lung fibroblasts (American Type Culture Collection, Rockville, MD) were cultured in
DME supplemented with penicillin ( $400 \mathrm{U} / \mathrm{ml})$, streptomycin $(50 \mu \mathrm{g}$ / $\mathrm{ml})$, glutamine $(300 \mu \mathrm{g} / \mathrm{ml})$, and $10 \%$ fetal calf serum in a humidified atmosphere of $7 \% \mathrm{CO}_{2}$ at $37^{\circ} \mathrm{C}$. Primary cultures of human umbilical vein endothelial cells (HUVEC) (Clonetics, San Diego, CA), were cultured in endothelial cell growth medium (EGM ${ }^{\mathrm{TM}}$ ) (Clonetics) at $37^{\circ} \mathrm{C}$ in a humidified atmosphere of $7 \% \mathrm{CO}_{2}$. HUVEC cells between passages 3 and 6 were used for migration studies. Bone marrow-derived murine macrophages were isolated as described (35) and cultured in DME containing $2 \mathrm{mM}$ L-glutamine, $1 \mathrm{mM} \mathrm{Na}$ pyruvate, $50 \mathrm{U} / \mathrm{ml}$ penicillin, $50 \mu \mathrm{g} / \mathrm{ml}$ streptomycin, $20 \%$ FCS, and $30 \%$ L-cell conditioned medium (as a source of macrophage colony stimulating factor) (35) on nontissue culture plastic in a humidified $5 \% \mathrm{CO}_{2}$ atmosphere.

Cell migration assays. Migration assays were conducted using the modified Boyden chamber as described (36). Briefly, the chamber consists of two compartments separated by a filter, and migration is measured by counting the number of cells crossing the membrane through pores of defined size. Lower chambers were filled with dialyzed or undialyzed wound fluid collected $24 \mathrm{~h}$ after injury. Various $\mathrm{CaCl}_{2}$ or $\mathrm{MgCl}_{2}$ concentrations were then added as indicated. 5-10- $\mu \mathrm{m}$ pore polycarbonate membrane filters (Poretics Corp., Livermore, CA) that had been previously coated with $25 \mu \mathrm{g} / \mathrm{ml}$ bovine type I collagen or 10 $\mu \mathrm{g} / \mathrm{ml}$ bovine fibrinogen were then placed on top of the lower chambers, and the upper chambers were secured in place. Upper chambers were filled with medium containing $5.0 \times 10^{4} \mathrm{HaCaT}$ keratinocytes, 3.0 $\times 10^{4}$ WI38 fibroblasts, $3.0 \times 10^{4}$ human umbilical vein endothelial cells, or $5.0 \times 10^{5}$ bone marrow-derived murine macrophages per chamber using $\mathrm{Ca}^{2+}, \mathrm{Mg}^{2+}$, and $\mathrm{PO}_{4}$-free DME supplemented with $\mathrm{Ca}^{2+}$ and $\mathrm{Mg}^{2+}$ concentrations consistent with the lower chambers, plus 100 $\mu \mathrm{g} / \mathrm{ml}$ BSA. The entire apparatus was then incubated for $4 \mathrm{~h}$ at $37^{\circ} \mathrm{C}$. After the incubation period, the upper chamber was removed and the filter was fixed in 3\% paraformaldehyde in PBS and stained with $0.5 \%$ toluidine blue and $3.7 \%$ formaldehyde in PBS. Excess stain was washed away with water, the attached cells on the upper side of the filter were removed and the cells that had migrated to the underside were quantitated by counting two high-powered fields $(\times 200)$ per well using an inverted, light microscope (model CK2; Olympus Corp., Lake Success, NY).

Protein. Bovine type I collagen was obtained from Collaborative Research Inc. (Bedford, MA). Bovine plasma fibrinogen was obtained from Calbiochem (La Jolla, CA).

\section{Results}

Extracellular $\mathrm{Mg}^{2+}$ and $\mathrm{Ca}^{2+}$ concentrations change during wound healing. Because integrin-mediated leukocyte adhesion and fibroblast, keratinocyte and endothelial cell migration are affected by the relative concentrations of extracellular $\mathbf{M g}^{2+}$ and $\mathrm{Ca}^{2+}$ in vitro $(13,22,36-40),{ }^{1}$ experiments were conducted to measure the levels of extracellular $\mathrm{Mg}^{2+}$ and $\mathrm{Ca}^{2+}$ in an in vivo setting known to involve these cells and these integrinextracellular matrix interactions, i.e., the early stages of cutaneous injury repair $(1-8,33,34)$. We observed that the $\mathrm{Mg}^{2+}$ concentration in porcine wound fluid from partial-thickness excisional wounds was increased from 0.96 to $1.43 \mathrm{mM}$ immediately after wounding, while the $\mathrm{Ca}^{2+}$ concentration was reduced from $2.53 \mathrm{mM}$ to $1.59 \mathrm{mM}$ (Fig. $1 A$ ). This represents a shift in the $\mathrm{Mg}^{2+}$ to $\mathrm{Ca}^{2+}$ ratio from 0.38 to 0.90 (Fig. $1 \mathrm{~B}$ ). The existing data correlating cell migration activity with extracellular ratios of $\mathrm{Mg}^{2+}$ to $\mathrm{Ca}^{2+}$ indicate that the shift in divalent cation concentrations observed in this wound fluid is sufficient to support nearly maximal migratory activity of human WI38 fibroblasts, $\mathrm{HaCaT}$ keratinocytes and capillary endothelial cells $(18,36) .{ }^{1}$ To confirm that the observed cation concentrations in this early wound fluid were altered as a consequence of wounding, time course studies were conducted. Using partialthickness burn (Fig. 2, $A$ and $B$ ) and full-thickness incisional 
A

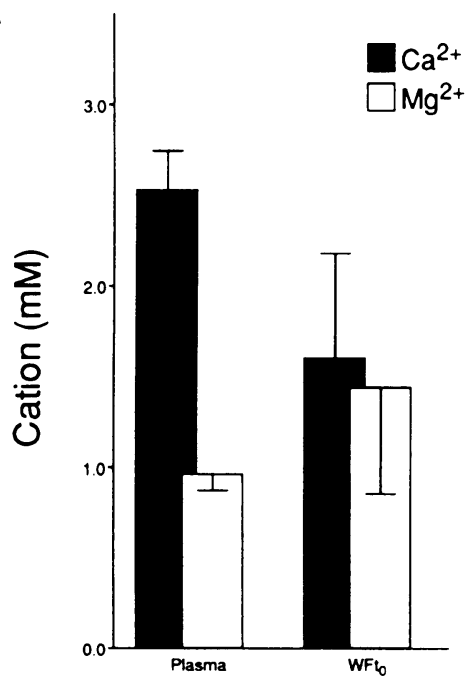

B

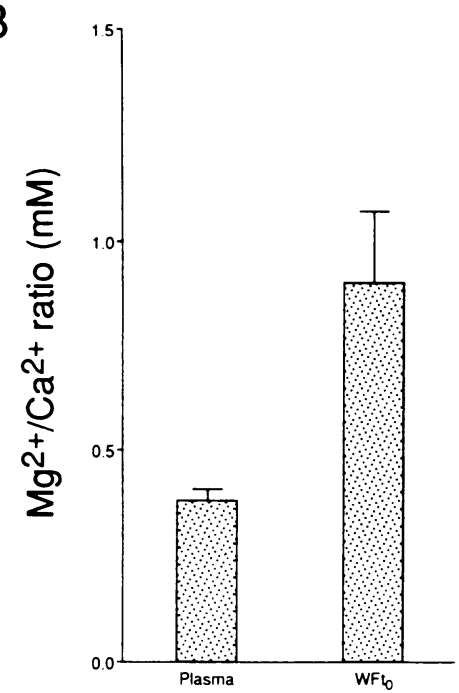

Figure 1. Evaluation of the extracellular $\mathrm{Mg}^{2+}$ and $\mathrm{Ca}^{2+}$ levels in wound fluid obtained immediately after injury from a porcine, partialthickness model of wound healing. $(A)$ $\mathrm{Mg}^{2+}$ and $\mathrm{Ca}^{2+}$ levels in wound fluid collected immediately after wounding $\left(t_{0}\right)$ are shown. (B) The $\mathrm{Mg}^{2+}$ to $\mathrm{Ca}^{2+}$ ratio in $\mathrm{t}_{0}$ wound fluid is compared with that of normal plasma obtained before surgery. The wound fluid results represent the mean $\pm S D$ of four animals, each with two wounds. The plasma values represent the mean $\pm S D$ of the four animals used in the study.

(Fig. 3, $A$ and $B$ ) models in the rat for wound fluid collection, we found that the $\mathrm{Mg}^{2+}$ to $\mathrm{Ca}^{2+}$ ratio observed in porcine wound fluid immediately after injury was maintained in these two models through at least $24 \mathrm{~h}$, with values ranging between 0.85 and 0.98 . The levels of the two cations overall were somewhat lower in the rat models than those observed in the porcine model, with concentrations ranging between 0.89 and $1.3 \mathrm{mM}$. As wound healing progressed $(48 \mathrm{~h})$, the levels of the two cations appear to begin to return to those normally found in plasma. At the indicated time-points of the full-thickness/PVA sponge rat experiments, plasma was also collected. It was determined that the plasma levels of $\mathrm{Mg}^{2+}$ and $\mathrm{Ca}^{2+}$ were not significantly different from those measured in plasma before injury (not shown).

The altered concentrations of $\mathrm{Mg}^{2+}$ and $\mathrm{Ca}^{2+}$ found in wound fluid 24 h after injury promotes maximal macrophage, keratinocyte, fibroblast, and endothelial cell migration. During cutaneous injury repair in vivo, the inflammatory cell types macrophages and neutrophils arrive at the wound site together within hours after injury (1-4). Keratinocytes have also been shown to become activated within hours after injury and to migrate measureably within the first $24 \mathrm{~h}$ after injury (1-8). Additionally, fibroblasts and neovasculature have been shown
A
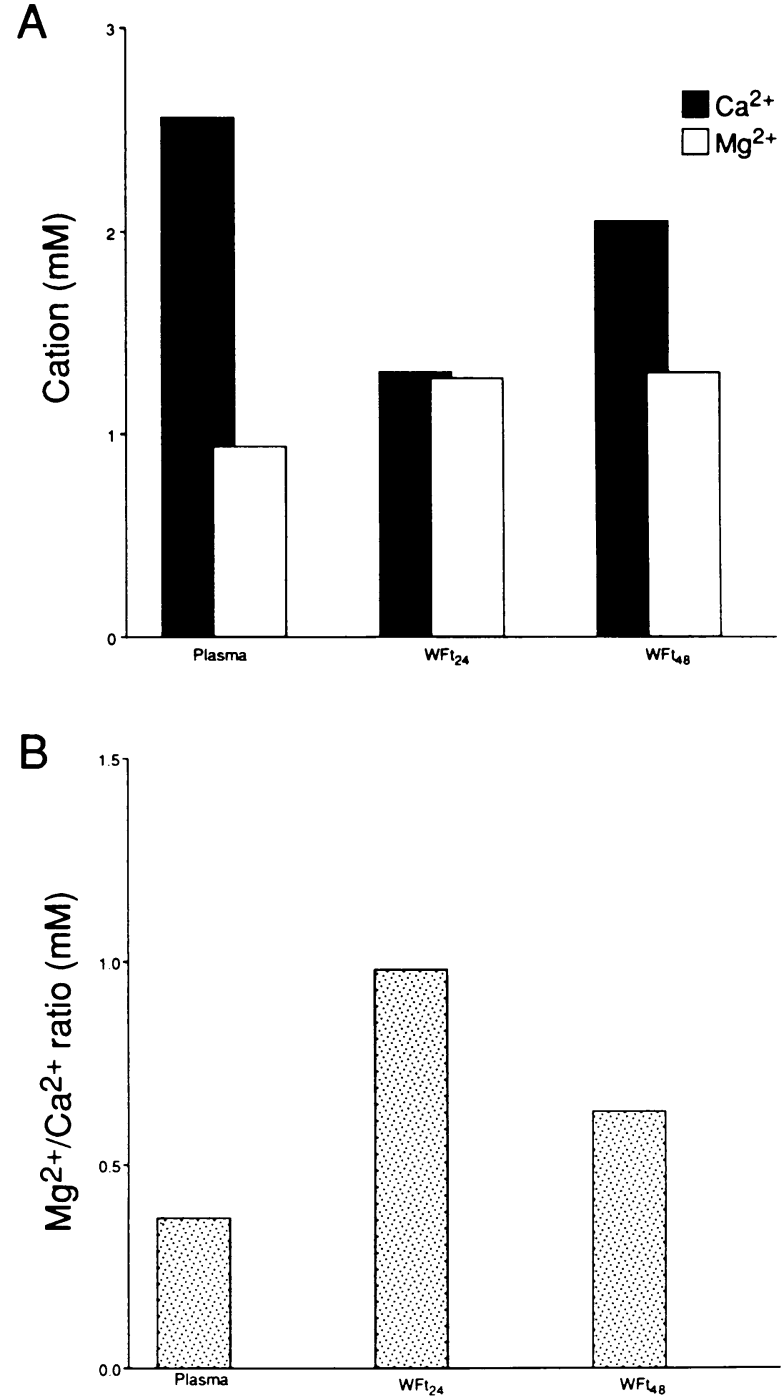

Figure 2. Time course evaluation of extracellular $\mathrm{Mg}^{2+}$ and $\mathrm{Ca}^{2+}$ levels in wound fluid from a rat, partial-thickness burn model of wound healing. (A) $\mathrm{Mg}^{2+}$ and $\mathrm{Ca}^{2+}$ levels in wound fluid are indicated with respect to time throughout a 48 -h time course $\left(W{ }^{2} t_{24}\right.$ and $\left.W F t_{48}\right)$ and compared with normal plasma levels. $(B)$ The $\mathrm{Mg}^{2+}$ and $\mathrm{Ca}^{2+}$ ratio in wound fluid throughout the time course is shown and compared with the ratio found in normal plasma obtained prior to wounding. The data represent the mean values of the cations found in wound fluid derived from single wounds on each of two rats. In no case did the individual cation concentrations differ by $>8 \%$.

to migrate into the wound site from surrounding tissue between 1 and $3 \mathrm{~d}$ after injury where they begin the process of granulation tissue formation $(1-8)$. Fibrin (ogen) is a major component of the initial clot $(1-4)$. It has been previously demonstrated that the $\beta_{2}$ integrin Mac- 1 mediates the binding of macrophages and neutrophils to fibrinogen $(37,41-48)$. It has also been demonstrated that $\beta_{2}$ integrin adhesive function is $\mathrm{Mg}^{2+}$. dependent and inhibited by $\mathrm{Ca}^{2+}$ similar to $\alpha_{2} \beta_{1}(13,39)$. If the epithelial basement membrane is disrupted, keratinocytes are directly exposed to type I collagen in the underlying interstitium. Fibroblasts and neovasculature migrating into the wound site from surrounding tissue would likely do so, at least in part, on type I collagen. Additionally, type I collagen is the major newly synthesized protein during cutaneous injury repair (1- 

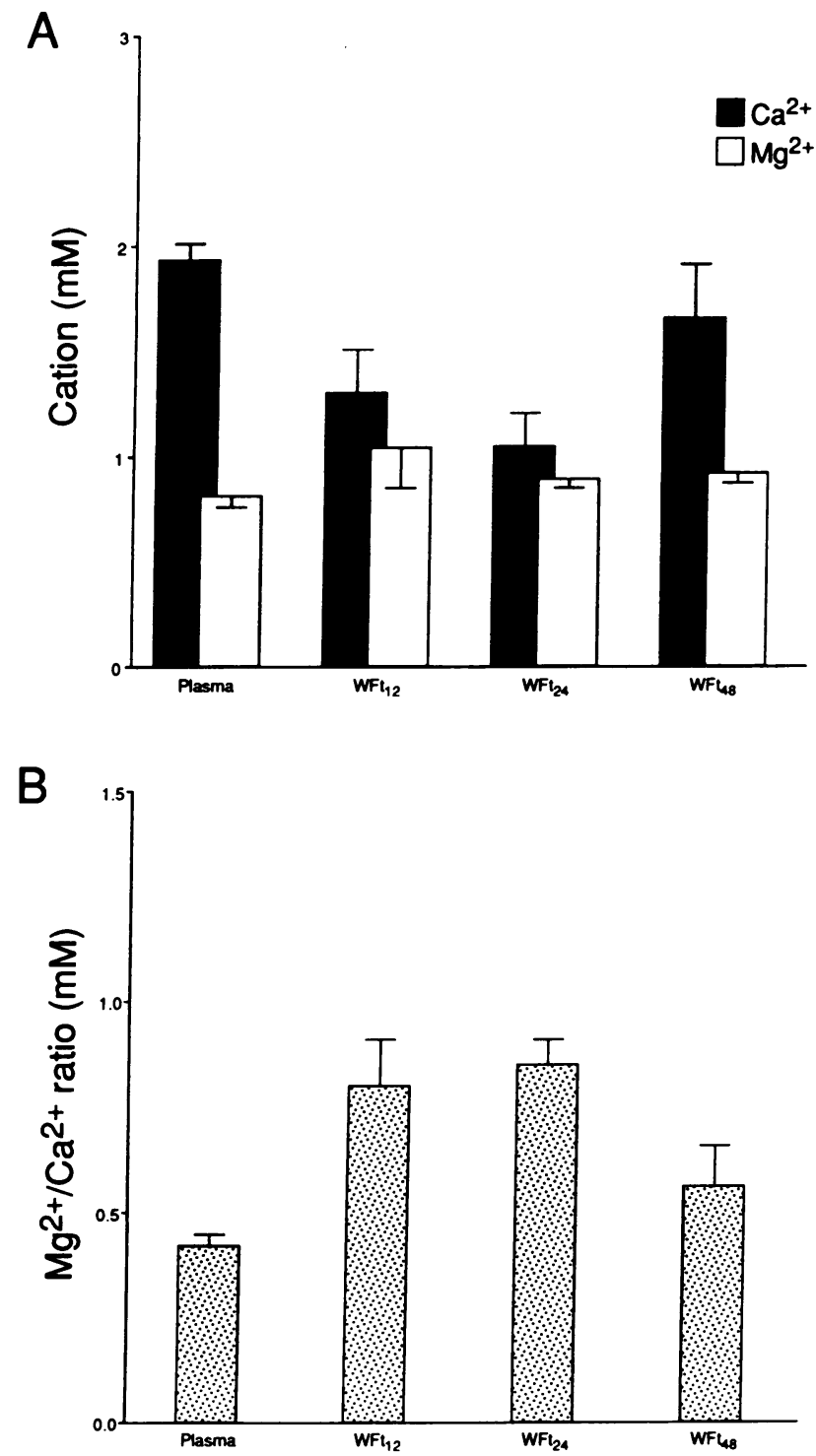

Figure 3. Time course evaluation of extracellular $\mathrm{Mg}^{2+}$ and $\mathrm{Ca}^{2+}$ levels in wound fluid from a rat, full-thickness/PVA sponge model of wound healing. $(A) \mathrm{Mg}^{2+}$ and $\mathrm{Ca}^{2+}$ levels in wound fluid are indicated with respect to time throughout a 48 -h time course $\left(W F t_{12}, W F t_{24}\right.$, and $\left.W F t_{48}\right)$ and compared with normal plasma levels. $(B) \mathrm{The}^{\mathrm{Mg}^{2+}}$ to $\mathrm{Ca}^{2+}$ ratio in wound fluid throughout the time course is indicated and compared to the ratio found in normal plasma obtained before surgery. The results represent the mean values \pm SD of the cations found in wound fluid derived from four wounds on each of two animals per time point. The plasma values (obtained before surgery) represent the mean \pm SD of the six animals used in the study.

$4,33,34)$. It has been previously demonstrated that the $\alpha_{2} \beta_{1}$ integrin, whose divalent cation dependent nature has been well documented, is present on these keratinocytes, fibroblasts and endothelial cells in vivo during wound healing, and that this integrin mediates the migration of these cells on type I collagen $(5,6,22,33,38)$.

To test the effect of the shifted divalent cation concentrations found in wound fluid on migration of these important wound healing cell types, wound fluid collected from individual sponges in the full-thickness/PVA sponge rat model $24 \mathrm{~h}$ after injury was divided into two aliquots. One aliquot was dialyzed extensively against cation-free tris-buffered saline. The dialysis tubing had a molecular weight cut-off of 6-8 $\mathrm{kD}$. We then tested these two wound fluid aliquots (dialyzed and not dialyzed) for their ability to promote the migration of bone marrow-derived murine macrophages on fibrinogen, and WI38 fibroblasts, HaCaT keratinocytes, and umbilical vein endothelial cells on type I collagen. In the wells that contained dialyzed wound fluid supplemented with divalent cations, maximal migration equivalent to that of the undialyzed wound fluid was achieved when $\mathrm{Mg}^{2+}$ and $\mathrm{Ca}^{2+}$ were added at concentrations observed 24 hours after injury (Fig. 4, $A-D$ ). Some migration was observed in the wells containing normal plasma levels of $\mathrm{Mg}^{2+}$ and $\mathrm{Ca}^{2+}$, but the activity was about half that observed with wound fluid cation levels observed $24 \mathrm{~h}$ after injury. Essentially all adhesive and, consequently, migratory activity was lost for all four cell types when dialyzed wound fluid was used with no added divalent cations.

\section{Discussion}

We demonstrate that during the early stages of cutaneous injury the concentrations of extracellular $\mathrm{Mg}^{2+}$ and $\mathrm{Ca}^{2+}$ in porcine and rat wound fluids are significantly different from those observed in normal extracellular fluid. Specifically, $\mathrm{Mg}^{2+}$ is elevated and $\mathrm{Ca}^{2+}$ is reduced. This early wound fluid, after dialysis against divalent cation-free Tris-buffered saline, is essentially unable to promote the adhesion, and consequently, the migration of macrophages on fibrinogen, or keratinocytes, fibroblasts and endothelial cells on type I collagen. With the addition of $\mathbf{M g}^{2+}$ and $\mathrm{Ca}^{2+}$ to the dialyzed wound fluid in the concentrations observed in wound fluid obtained $24 \mathrm{~h}$ after injury, however, all migration-promoting activity is restored. This represents a nearly twofold increase in migration over that observed in response to dialyzed wound fluid supplemented with normal plasma levels of the two cations.

During the initial acute inflammatory response to injury platelets become activated for aggregation and secretion responses. It is well established that type I collagen promotes platelet aggregation and that the $\alpha_{2} \beta_{1}$ integrin present on platelets responds to $\mathrm{Mg}^{2+}$ and $\mathrm{Ca}^{2+}$ in adhesion studies similar to fibroblasts (49). Interestingly, addition of $\mathrm{Mg}^{2+}$ to platelets gelfiltered in the absence of $\mathrm{Mg}^{2+}$ and $\mathrm{Ca}^{2+}$ promotes optimal aggregation and secretion responses while $\mathrm{Ca}^{2+}$ promotes disaggregation $(50,51)$. It is possible that an initial burst of $\mathrm{Mg}^{2+}$ provided by damaged cells, which contain intracellular $\mathbf{M g}^{2+}$ concentrations in excess of $15 \mathrm{mM}$ (25-28), and exposure to type I collagen could collectively induce the aggregation response. Macrophages and neutrophils also become activated during this phase, extravasating through the blood vessel wall, surrounding tissue and into the wound site. This activation is characterized by a conformational change in $\beta_{2}$ integrins that renders them functional for ligand binding $(9-12)$. It is interesting that this conformational change has been shown to be $\mathrm{Mg}^{2+}$ dependent $(13,39,40)$. These data are in agreement with our macrophage results which demonstrate enhanced $\beta_{2}$ integrinmediated migration on fibrinogen when $\mathrm{Mg}^{2+}$ is increased and $\mathrm{Ca}^{2+}$ is reduced.

Also occurring during the middle of the inflammatory response, by $\sim 24 \mathrm{~h}$ after injury, keratinocytes also become " activated" and measurable migration is observed (1-6, 52-57). How this "activation" process occurs has not been clearly defined. Mansbridge and Knapp (56), have noted that because keratinocytes proliferate and migrate at the injury edge, the 
A

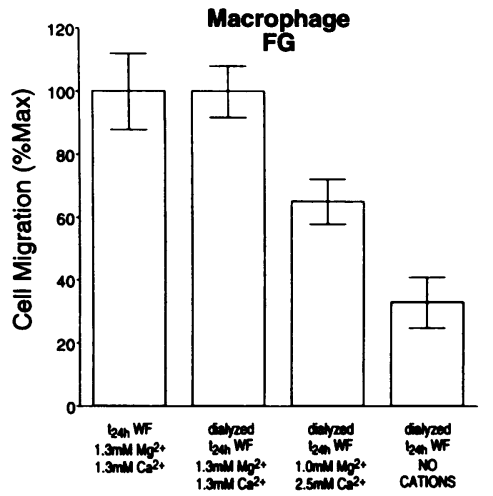

C

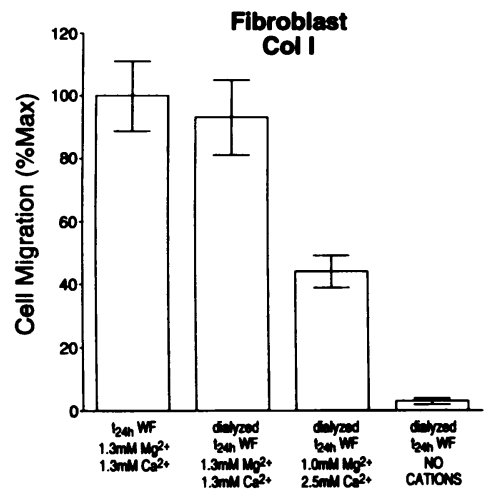

B

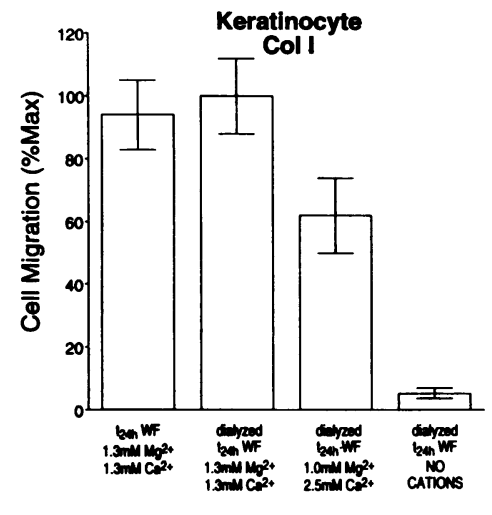

D

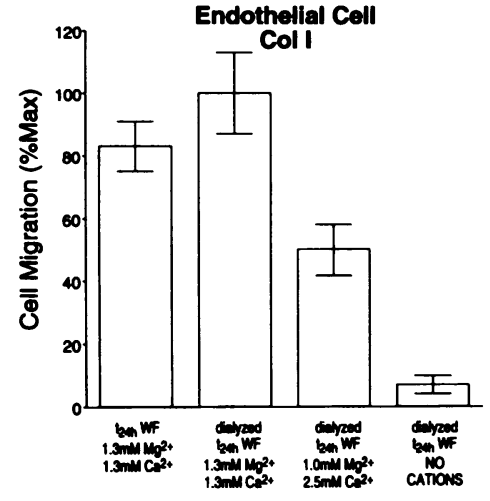

Figure 4. Effect of the shifted $\mathrm{Mg}^{2+}$ and $\mathrm{Ca}^{2+}$ concentrations in wound fluid $24 \mathrm{~h}$ after injury on the migratory activity of macrophages on fibrinogen, and keratinocytes, fibroblasts, and endothelial cells on type I collagen. In medium containing the indicated cation concentrations, $5.0 \times 10^{5}$ bone marrow-derived murine macrophages $(A), 5.0 \times 10^{4} \mathrm{HaCaT}$ keratinocytes $(B), 3.0 \times 10^{4}$ WI38 fibroblasts $(C)$, or $3.0 \times 10^{4}$ umbilical vein endothelial cells $(D)$ were added to the upper chamber of a modified Boyden chamber and allowed to migrate for $4 \mathrm{~h}$ at $37^{\circ} \mathrm{C}$ through fibrinogen-coated $(10 \mu \mathrm{g} / \mathrm{ml})$ or type I collagen-coated $(25 \mu \mathrm{g} / \mathrm{ml})$ filters of defined pore size $(5-10 \mu \mathrm{m})$ toward dialyzed or undialyzed $24-\mathrm{h}$ rat wound fluid (supplemented or not with cations consistent with those of the upper chamber) in the lower chamber. Filters were fixed, stained, and adherent cells were removed from the top of the filter. The cells that had migrated to the underside of the filters were counted as described in Methods. The results represent the mean $\pm S D$ of three to five experiments done in triplicate. $100 \%$ is 293 bone marrow-derived murine macrophages, 103 human umbilical vein endothelial cells, 75 WI38 human fibroblasts, or 66 human $\mathrm{HaCaT}$ keratinocytes per high power field. $\times 200$. signal to do so must originate at the injury site. Additionally, Clark (57), observed that keratinocytes some distance from the actual wound also become activated and suggests that some diffusable wound factor must be present. Our data would suggest that the diffusible factor/signal is, at least in part, the shift in the levels of extracellular $\mathrm{Mg}^{2+}$ and $\mathrm{Ca}^{2+}$ set up locally from the wound site.

Fibroblasts and endothelial cells, other important cell types involved in wound healing, have been shown to begin arriving at the wound site between 1 and $3 \mathrm{~d}$ after wounding, marking the beginning of the second phase of wound healing, granulation tissue formation (1-8). To begin arriving from surrounding tissue by $1-3 \mathrm{~d}$ after injury they must also begin migrating in from surrounding tissue during the initial inflammatory phase of wound repair. The diffusible divalent cation gradient set up in the area surrounding the actual wound could provide the stimulus for these cell types to react to chemotactic factors released into the wound, resulting in migration into the wound site.

In vitro studies with fibroblasts and keratinocytes indicate increasing migration as the $\mathrm{Mg}^{2+}$ to $\mathrm{Ca}^{2+}$ ratio approaches one (22). ${ }^{1}$ Evaluation of wound fluid cation concentrations showed approximately equal concentrations of $\mathrm{Mg}^{2+}$ and $\mathrm{Ca}^{2+}$ early in the wound healing response, which would favor greater than $90 \%$ of maximal migration according to existing data. Once the wound is closed, however, it becomes impossible to definitively measure, by our macro-technique, the actual extracellular cation concentrations in the micro-environment at the wound edge. The PVA sponges that were placed beneath the full-thickness incisional wounds to obtain sufficient wound fluid volumes are potentially exposed to normal extracellular fluid from the interstitium and blood which may dilute $\mathrm{Mg}^{2+}$ and $\mathrm{Ca}^{2+}$ shifts that are occurring. It is possible that the cation shifts are more pronounced and maintained longer than $48 \mathrm{~h}$. In support of this idea, Schilling et al. (58), reported that 7-d wound fluid still contained $\mathrm{Ca}^{2+}$ at levels similar to our $24 \mathrm{~h}$ results. Unfortunately, $\mathrm{Mg}^{2+}$ was not measured, nor were any other timepoints. This study does demonstrate, however, at least with extracellu$\operatorname{lar} \mathrm{Ca}^{2+}$, that the initial shift in cation concentrations may be maintained for at least $7 \mathrm{~d}$ after injury.

It is possible to envision how a shift in the ratio of these two cations might occur locally after injury, as the concentration of $\mathrm{Mg}^{2+}$ inside a mammalian cell is $\sim 10$ times that of $\mathrm{Ca}^{2+}$ (25-28). The simple spilling of $\mathrm{Mg}^{2+}$ from damaged cells and the sequestration of $\mathrm{Ca}^{2+}$ by several possible molecular events, including the coagulation cascade (30-32), could account for the observed shift. However, our findings suggest that these shifted cation concentrations are maintained beyond $24 \mathrm{~h}$ after the initial injury. It is unclear how this occurs.

Numerous reports over the past 15 years have demonstrated that early wound fluid increases and that late wound fluid inhibits the migration and proliferation of all cells required for wound healing, including fibroblasts, endothelial cells, smooth muscle cells, keratinocytes, and leukocytes (59-67). There has been intense interest in the role of growth factors in the regulation of these cellular responses. Several have been found in wound fluid various times during wound healing and shown to stimulate or inhibit cell proliferation and/or migration, including platelet-derived growth factor, epidermal growth factor, macrophage-derived growth factor, transforming growth factor-beta, insulin-like growth factor-1, interleukins, an angiogenesis factor, migration stimulating factor, and fibroblast growth factor $(65-77)$. Their precise mechanisms of action have not been elucidated. In addition to increased protein phosphorylation (78), which is $\mathrm{Mg}^{2+}$ dependent (79), and alterations in the actin cytoskeleton $(80)$, which has been shown to be differentially affected by $\mathrm{Mg}^{2+}$ and $\mathrm{Ca}^{2+}(81)$, many of these growth factors are associated with transmembrane $\mathrm{Ca}^{2+}$ or $\mathrm{Mg}^{2+}$ fluxes $(82-$ 
84) and could participate in the regulation of divalent cation concentrations. Despite the presence of these growth factors in wound fluid, however, our data demonstrate that the presence and concentrations of $\mathrm{Mg}^{2+}$ and $\mathrm{Ca}^{2+}$ can account for the increased ability of cells to migrate. Similar increases in migration have been reported using altered concentrations of $\mathrm{Mg}^{2+}$ and $\mathrm{Ca}^{2+}$ with platelet-derived growth factor alone or fetal calf serum $(22,35) .{ }^{1}$ It may be that the growth factors found in wound fluid and fetal calf serum provide directional signalling for cell movement. The alterations in the concentrations of extracellular $\mathrm{Mg}^{2+}$ and $\mathrm{Ca}^{2+}$ may act in conjunction with growth factors by creating conditions that favor increased and directed migration.

Chronic wound fluid from venous stasis and to a lesser degree, diabetic ulcers show significant breakdown of fibronectin and vitronectin along with increased metalloprotease activity $(85,86)$. The concentrations of $\mathrm{Ca}^{2+}$ and $\mathrm{Mg}^{2+}$ in these wound fluids were not measured, however. Interestingly, Sank et al. (87), demonstrated in a guinea pig model that increasing the $\mathrm{Ca}^{2+}$ concentration at the wound site resulted in increased collagenase activity and poor wound closure characteristic of a chronic wound. It is possible that the $\mathrm{Mg}^{2+}$ and $\mathrm{Ca}^{2+}$ concentrations in a chronic wound are not optimal for proper wound healing. The resultant increase in protease activity and inhibition of integrin-extracellular matrix interactions could easily lead to a chronic situation.

In conclusion, local shifts in the concentrations of extracellular $\mathrm{Mg}^{2+}$ and $\mathrm{Ca}^{2+}$ appear to occur during wound healing, impacting the function of divalent cation-dependent cell surface molecules responsible for cell-cell and cell-extracellular matrix interactions. The altered function of these molecules in response to these divalent cation fluctuations can account for the ability of cells to migrate toward the site of a wound. It may be important therefore to consider the divalent cation concentrations when assessing conditions such as chronic wounds.

\section{Acknowledgments}

We wish to thank Dr. S. Reeder and C.L. Technologies (Corona, CA) for expert atomic absorption spectroscopy services; P. Stephan and R. Pieters of H.T.I. Bio-Services, Inc., for technical expertise in the execution of animal studies; Drs. R. Tamura, J. Glass, and J. Polarek for helpful discussions in the design and implementation of animal studies; Dr. R. Maki for the BMM's; and Drs. E. Pasquale, E. Engvall, K. Vuori, and E. Ruoslahti for helpful discussions and critical readings of the manuscript.

This work was funded by a grant from Telios Pharmaceuticals, Inc. (La Jolla, CA).

\section{References}

1. Clark, R. A. F. 1985. Cutaneous tissue repair: basic biologic considerations. J. Am. Acad. Dermatol. 13:701-725.

2. Clark, R. A. F. 1989. Wound repair. Curr. Opin. Cell Biol. 1:1000-1008.

3. Clark, R. A. F., and P. M. Henson. 1988. The molecular and cellular biology of wound repair. Plenum Press, New York. 1-597.

4. Woodley, D. T. 1985. Cutaneous wound healing: a model for cell-matrix interactions. J. Am. Acad. Dermatol. 12:420-433.

5. Larjava, H., T. Salo, K. Haapasalmi, R. J. Kramer, and J. Heino. 1993. Expression of integrins and basement membrane components by wound keratinocytes. J. Clin. Invest. 92:1425-1435.

6. Juhasz, I., G. F. Murphy, H. Yan, M. Herlyn, and S. M. Albeda. 1993. Regulation of extracellular matrix proteins and integrin cell substratum adhesion receptors on epithelium during cutaneous human wound healing in vivo. Am. J. Pathol. 143:1458-1469.

7. Schilling, J. A., B. V. Favata, and M. Radakovich. 1953. Studies of fibroplasia during wound healing. Surg. Gynecol. \& Obstet. 96:143-149.

8. Viljanto, J. 1976. Cellstic: a device for wound healing studies in man. Description of the method. J. Surg. Res. 20:115-119.
9. Hemler, M. E. 1990. VLA proteins in the integrin family: structures, functions, and their role on leukocytes. Annu. Rev. Immunol. 8:365-400.

10. Hynes, R. O. 1987. Integrins: versatility, modulation, and signaling in cell adhesion. Cell. 69:11-25.

11. Ruoslahti, E. 1991. Integrins. J. Clin. Invest. 87:1-5.

12. Springer, T. A. 1990. Adhesion receptors of the immune system. Nature (Lond.). 346:425-434

13. Dransfield, I., and N. Hogg. 1989. Regulated expression of $\mathrm{Mg}^{2+}$ binding epitope on leukocyte integrin $\alpha$ subunits. EMBO (Eur. Mol. Biol. Organ.) J. 8:3759-3765.

14. Ruoslahti, E., and M. D. Pierschbacher. 1987. New perspectives in cell adhesion: RGD and integrins. Science (Wash. DC). 238:285-296.

15. Fujimura, K., and D. R. Phillips. 1983. Calcium cation regulation of glycoprotein IIb-IIIa complex formation in platelet plasma membranes. J. Biol. Chem. 258:10247-10252.

16. Fitzgerald, L. A., and D. R. Phillips. 1985. Calcium regulation of the platelet membrane glycoprotein IIb-IIIa complex. J. Biol. Chem. 260:1136611374.

17. Argraves, W. S., S. Suzuki, H. Arai, K. Thompson, M. D. Pierschbacher, and E. Ruoslahti. Amino acid sequence of the human fibronectin receptor. J. Cell Biol. 105:1183-1190.

18. Kirchhofer, D., J. Grzesiak, and M. D. Pierschbacher. 1991. Calcium as a potential physiological regulator of integrin-mediated cell adhesion. J. Biol. Chem. 266:4471-4477.

19. Vogel, B. E., G. Tarone, F. G. Giancotti, J. Gailit, and E. Ruoslahti. 1990. A novel fibronectin receptor with an unexpected subunit composition $\left(\alpha_{v} \beta_{1}\right) . J$. Biol. Chem. 265:5934-5937.

20. Bodary, S. C., and J. W. McLean. 1990. The integrin $\beta_{1}$ subunit associates with the vitronectin receptor $\alpha_{\mathrm{v}}$ subunit to form a novel vitronectin receptor in a human embryonic kidney cell line. J. Biol. Chem. 265:5938-5941.

21. Pytela, R., M. D. Pierschbacher, and E. Ruoslahti. 1985. Identification and isolation of a $140 \mathrm{kD}$ cell surface glycoprotein with properties expected of a fibronectin receptor. Cell. 40:191-198.

22. Grzesiak, J. J., G. E. Davis, D. Kirchhofer, and M. D. Pierschbacher. 1992. Regulation of $\alpha_{2} \beta_{1}$-mediated fibroblast migration on type I collagen by shifts in the concentrations of extracellular $\mathrm{Mg}^{2+}$ and $\mathrm{Ca}^{2+}$. J. Cell Biol. 117:1109-1117.

23. Takeichi, M. 1991. Cadherin cell adhesion receptors as a morphogenetic regulator. Science (Wash. DC). 251:1451-1455.

24. Ranscht, B. 1991. Cadherin cell adhesion molecules in vertebrate neural development. Semin. Neurosci. 3:285-296.

25. Polimeni, P. I., and E. Page. 1973. Magnesium in heart muscle. Circ. Res. 33:367-374.

26. Henrotte, J. G. 1988. Genetic regulation of blood and tissue magnesium content in mammals. Magnesium. 7(5-6):306-314.

27. Caddell, J. L., and G. F. Reed. 1989. Validity of the parenteral magnesium load test for mature mammals. Magnesium. 8(2):65-70.

28. Alberts, B., D. Bray, J. Lewis, M. Raff, K. Roberts, and J. D. Watson, editors. 1989. Molecular Biology of the Cell. Garland Publishing, Inc., New York. $301 \mathrm{pp}$.

29. Olinger, M. L. 1989. Disorders of calcium and magnesium metabolism. Emerg. Med. Clin. North Am. 7:795-822.

30. Coller, B. S., editor. 1989. Progress in Hemostasis and thrombosis, Vol. 9. W. B. Sanders Co., Philadelphia, PA.

31. Cooper, M. S., and M. Schliwa. 1988. Ca-channels and amoeboid cell movement. In Signal Transduction in Cytoplasmic Organization and Cell Motility. P. Satir, J. S. Condelis, and E. Lazarides, editors. Alan R. Liss, Inc., New York. 271-278.

32. Fujimoto, T., K. Fujimura, and A. Kuramoto. 1991. Electrophysiological evidence that glycoprotein Ilb-IIIa complex is involved in calcium channel activation on human platelet plasma membrane. J. Biol. Chem. 266:16470-16375.

33. Scharffetter-Kochanek, K., C. E. Klein, G. Heinen, C. Mauch, T. Schaefer, B. C. Adelmann-Grill, G. Goerz, N. E. Fusenig, T. M. Krieg, and G. Plewig. 1992. Migration of a human keratinocyte cell line (Hacat) to interstitial collagen type I is mediated by the $\alpha_{2} \beta_{1}$-integrin receptor. J. Invest. Dermatol. 98:3-11.

34. Woodley, D. T., P. M. Bachmann, and E. J. O'Keefe. 1988. Laminin inhibits human keratinocyte migration. J. Cell. Physiol. 136:140-146.

35. Celada, A., and R. A. Maki. 1992. Transforming growth factor- $\beta$ enhances the M-CSF and GM-CSF stimulated proliferation of macrophages. J. Immunol. 148:1102-1105.

36. Banai, S., L. Haggroth, S. E. Epstein, and W. Casscells. 1990. Influence of extracellular magnesium on capillary endothelial cell proliferation and migration. Circ. Res. 67:645-650.

37. Altieri, D. C. 1991. Occupancy of CD11b/CD18 (Mac-1) divalent ion binding site(s) induces leukocyte adhesion. J. Immunol. 147:1891-1898.

38. Leavesley, D. I., M. A. Schwartz, M. Rosenfeld, and D. A. Cheresh. 1993. Integrin $\beta_{1}$ - and $\beta_{3}$-mediated endothelial cell migration is triggered through distinct signalling mechanisms. J. Cell Biol. 121:163-170.

39. Dransfield, I., C. Cabanas, A. Craig, and N. Hogg. 1992. Divalent cation regulation of the function of the leukocyte integrin LFA-1. J. Cell Biol. 116:219226. 
40. Davis, G. E., and C. W. Camarillo. 1993. Regulation of integrin-mediated myeloid cell adhesion to fibronectin: influence of disulfide reducing agents, divalent cations and phorbol ester. J. Immunol. 151:7138-7150.

41. Trezzini, C., B. Schuepp, F. E. Maly, and T. W. Jungi. 1991. Evidence that exposure to fibrinogen or to antibodies directed against Mac-1 (CD11b/ CD18: CR3) modulates human monocyte effector functions. Br. J. Haematol. 77:16-24.

42. Van Strijp, J. A., D. G. Russell, E. Tuomanen, E. J. Brown, and S. D. Wright. 1993. Ligand specificity of purified complement receptor type three (CD11b/CD18, alpha $\mathrm{m}$ beta 2, Mac-1). Indirect effects of an Arg-Gly-Asp (RGD) sequence. J. Immunol. 151:3324-3336.

43. Diamond, M. S., and T. A. Springer. 1993. A subpopulation of Mac-1 (CD11b/CD18) molecules mediates neutrophil adhesion to ICAM-1 and fibrinogen. J. Cell Biol. 120:545-556.

44. Kaufmann, Y., E. Tseng, and T. A. Springer. 1991. Cloning of the murine lymphocyte function-associated molecule-1 alpha-subunit and its expression in COS cells. J. Immunol. 147:369-374.

45. Altieri, D. C., J. Plescia, and E. F. Plow. 1993. The structural motif glycine 190-valine 202 of the fibrinogen gamma chain interacts with CD1 lb/CD18 integrin (alpha $\mathbf{M}$ beta 2, Mac-1) and promotes leukocyte adhesion. J. Biol. Chem. 268:1847-1853.

46. Loike, J. D., R. Silverstein, S. D. Wright, J. I. Weitz, A. J. Huang, and S. C. Silverstein. 1992. The role of protected extracellular compartments in interactions between leukocytes, and platelets, and fibrin/fibrinogen matrices. Ann. NY Acad. Sci. 667:163-172.

47. Elemer, G. S., and T. S. Edgington. 1994. Microfilament reorganization is associated with functional activation of alpha $\mathbf{M}$ beta 2 on monocytic cells. $J$. Biol. Chem. 269:3159-3166.

48. Simon, D. I., A. M. Ezratty, S. A. Francis, H. Rennke, and J. Loscalzo. 1993. Fibrin (ogen) is internalized and degraded by activated human monocytoid cells via Mac-1 (CD11b/CD18): a nonplasmin fibrinolytic pathway. Blood. 82:2414-2422.

49. Staatz, W. D., S. M. Rajpara, E. A. Wayner, W. G. Carter, and S. A. Santoro. 1989. The membrane glycoprotein Ia-IIa (VLA-2) complex mediates the $\mathrm{Mg}^{2+}$-dependent adhesion of platelets to collagen. J. Cell Biol. 108:19171924.

50. Mustard, J. F., D. W. Perry, R. L. Kinlough-Rarthbone, and M. A. Packham. 1975. Factors responsible for ADP-induced release reaction of human platelets. Am. J. Physiol. 228:1757-1763.

51. Lages, B., M. C. Scrutton, and H. Holmsen. 1975. Studies on gel-filtered human platelets: isolation and characterization in medium containing no added $\mathrm{Ca}^{2+}, \mathrm{Mg}^{2+}$ or $\mathrm{K}^{+}$. J. Lab. Clin. Med. 85:811-817.

52. Grinnell, F. 1990. The activated keratinocyte: up regulation of cell adhesion and migration during wound healing. J. Trauma. 30:S144-S149.

53. Grinnell, F. 1992. Wound repair, keratinocyte activation and integrin modulation. J. Cell Sci. 101:1-5.

54. Guo, M., K-I. Toda, and F. Grinnell. 1990. Activation of human keratinocyte migration on type I collagen and fibronectin. J. Cell Sci. 96:197-205.

55. Grinnell, F., K-I. Toda, and A. Takashima. 1987. Activation of keratinocyte fibronectin receptor function during cutaneous wound healing. J. Cell Sci. Suppl. 8:199-209.

56. Mansbridge, J. N., and A. M. Knapp. 1987. Changes in keratinocyte maturation during wound healing. J. Invest. Dermatol. 89:253-263.

57. Clark, R. A. F. 1990. Fibronectin matrix deposition and fibronectin receptor expression in healing and normal skin. J. Invest. Dermatol. 94:128S-134S.

58. Schilling, J. A., L. E. Milch, and Cardiovascular Research Group. 1955. Fractional analysis of experimental wound fluid. Proc. Soc. Exp. Biol. Med. 89:189-192.

59. Mills, C. D., V. E. Pricolo, J. E. Albina, and M. D. Caldwell. 1991 Concomitant macrophage activation and fibroblast/lymphocyte inhibition by wound fluid: the "arginine-deficiency of inflammation" is a partial explanation In Clinical and Experimental Approaches to Dermal and Epidermal Repair: Normal and Chronic Wounds. A. Barbul, editor. Wiley-Liss, Inc., New York. 193203.

60. Greenburg, G. B., and T. K. Hunt. 1978. The proliferative response in vitro of vascular endothelial and smooth muscle cells exposed to wound fluids and macrophages. J. Cell. Physiol. 97:353-360.

61. Jalkanen, M., T. Haapanen, A.-M. Lyytikainen, and H. Larjava. 1983. Wound fluids mediate granulation tissue growth phases. Cell Biol. Int. Rep. 7:745753.

62. Orredson, S. U., D. R. Knighton, H. Scheuenstuhl, and T. K. Hunt. 1983.
A quantitative in vitro study of fibroblast and endothelial cell migration in response to serum and wound fluid. J. Surg. Res. 35:249-258.

63. Alper, J. C., L. L. Tibbetts, and A. A. Sarazen, Jr. 1985. The in vitro response of fibroblasts to the fluid that accumulates under a vapor-permeable membrane. J. Invest. Dermatol. 84:513-515.

64. Pricolo, V. E., M. D. Caldwell, B. Mastrofrancesco, and C. D. Mills 1990. Modulatory activities of wound fluid on fibroblast proliferation and collagen synthesis. J. Surg. Res. 48:534-538.

65. Dvonch, V. M., R. J. Murphey, J. Matsuoka, and F. R. Grotendorst. 1992. Changes in growth factor levels in human wound fluid. Surgery (St. Louis). 112:18-23.

66. Katz, M. H., A. F. Alvarez, R. S. Kirsner, W. H. Eaglstein, and V. Falanga. 1991. Human wound fluid from acute wounds stimulates fibroblast and endothelial cell growth. J. Am. Acad. Dermatol. 25:1054-1058.

67. Chen, W. Y. J., A. A. Rogers, and M. J. Lydon. 1992. Characterization of biologic properties of wound fluid collected during early stages of wound healing. J. Invest. Dermatol. 99:559-564.

68. Banda, M. J., D. R. Knighton, T. K. Hunt, and Z. Werb. 1982. Isolation of a nonmitogenic angiogenesis factor from wound fluid. Proc. Natl. Acad. Sci. USA. 79:7773-7777.

69. Grotendorst, G. R., Y. Soma, K. Takehara, and M. Charette. 1989. EGF and TGF-alpha are potent chemoattractants for endothelial cells and EGF-like peptides are present at sites of tissue regeneration. Cell Physiol. 139:617-623.

70. Baird, A., and P. A. Walicke. 1989. Fibroblast growth factors. British Medical Bulletin. 45:438-452.

71. Cromack, D. T., M. B. Sporn, A. B. Roberts, M. J. Merino, L. L. Dart and J. A. Norton. 1987. Transforming growth factor beta levels in rat wound chambers. Surg. Res. 42:622-628.

72. Ford, H. R., R. A. Hoffmann, E. J. Wing, D. M. Magee, L. McIntyre, and R. L. Simmons. 1989. Characterization of wound cytokines in the sponge matrix model. Arch. Surg. 124:1422-1428.

73. Spencer, E. M., G. Skover, and T. K. Hunt. 1988. Somatomedins: do they play a pivotal role in wound healing? Prog. Clin. Biol. Res. 266:103-116.

74. Hunt, T. K. 1991. Wound fluid: the growth environment. In Clinical and Experimental Approaches to Dermal and Epidermal Repair: Normal and Chronic Wounds. Wiley-Liss, Inc., New York. 223-230.

75. Picardo, M., A-M. Grey, M. McGurk, I. Ellis, and S. L. Schor. 1992 Detection of migration stimulating activity in wound fluid. Exp. Mol. Pathol. 57:8-21.

76. Soma, Y., V. Dvonch, and G. R. Grotendorst. 1992. Platelet-derived growth factor AA homodimer is the predominant isoform in human platelets and acute human wound fluid. FASEB (Fed. Am. Soc. Exp. Biol.) J. 6:2996-3001.

77. Matsuoka, J., and G. R. Grotendorst. 1989. Two peptides related to plateletderived growth factor are present in human wound fluid. Proc. Natl. Acad. Sci. USA. 86:4416-4420.

78. Ek, B., and C.-H. Heldin. 1984. Use of an antiserum against phosphotyrosine for the identification of phosphorylated components in human fibroblas stimulated by platelet-derived growth factor. J. Biol. Chem. 259:11145-11152.

79. Lardy, H. A. 1951. The influence of inorganic ions on phosphorylation reaction. In Phosphorous Metabolism. Vol. 1. W. D. McElroy and O. Glass, editors. Johns Hopkins University Press, Baltimore, MD. p. 477.

80. Kadowaki, T., S. Koyasu, E. Nishida, T. Kadooka, H. Fukami, H. Sakai, F Takaku, and M. Kasuga. 1987. Insulin-like growth factors, insulin, and epiderma growth factor cause rapid cytoskeletal reorganization. J. Biol. Chem. 261:16141 16147.

81. Orlova, A., and E. H. Egelman. 1993. A conformational change in the actin subunit can change the flexibility of the actin filament. J. Mol. Biol. 232:334-341.

82. Tashjian, A. H., Jr., E. F. Voelkel, W. Lloyd, R. Derynck, M. E. Winkler, and L. Levine. 1986. Actions of growth factors on plasma calcium. J. Clin. Invest. 78:1405-1409.

83. Ives, H. E., and T. O. Daniel. 1987. Interrelationship between growth factor-induced $\mathrm{pH}$ changes and intracellular $\mathrm{Ca}^{2+}$. Proc. Natl. Acad. Sci. USA. $84: 1950-1956$.

84. Gow, C. B., M. Wilkinson, M. J. Silvapulle, and G. P. Moore. 1992. Fluid Balance, electrolyte profiles and plasma parathyroid hormone concentrations in ewes treated with epidermal growth factor. J. Endocrinol. 135:91-101.

85. Wysocki, A. B., and F. Grinnell. 1990. Fibronectin profiles in normal and chronic wound fluid. Lab. Invest. 63:825-831.

86. Grinnell, F., C. H. Ho, and A. Wysocki. 1992. Degradation of fibronectin and vitronectin in chronic wound fluid: analysis by celi blotting, immunoblotting, and cell adhesion assays. J. Invest. Dermatol. 98:410-416.

87. Sank, A., M. Chi, T. Shima, R. Reich, and G. R. Martin. 1989. Increased calcium levels alter cellular and molecular events in wound healing. Surgery (St. Louis ). 106:1141-1148. 